\title{
Improving Antigenicity of the Recombinant Hepatitis C Virus Core Protein via Random Mutagenesis
}

\author{
Chen-Ji Huang, ${ }^{1}$ Hwei-Ling Peng, ${ }^{1}$ and Chih-Yu Cheng ${ }^{2}$ \\ ${ }^{1}$ Department of Biological Science and Technology, National Chiao Tung University, Hsinchu 30010, Taiwan \\ ${ }^{2}$ Department of Marine Biotechnology, National Kaohsiung Marine University, Kaohsiung 81143, Taiwan
}

Correspondence should be addressed to Hwei-Ling Peng, hlpeng@mail.nctu.edu.tw

and Chih-Yu Cheng, cycheng@mail.nkmu.edu.tw

Received 14 March 2011; Accepted 10 May 2011

Academic Editor: Shahid Jameel

Copyright (C) 2011 Chen-Ji Huang et al. This is an open access article distributed under the Creative Commons Attribution License, which permits unrestricted use, distribution, and reproduction in any medium, provided the original work is properly cited.

\begin{abstract}
In order to enhance the sensitivity of diagnosis, a recombinant clone containing domain I of HCV core (amino acid residues 1 to 123) was subjected to random mutagenesis. Five mutants with higher sensitivity were obtained by colony screening of 616 mutants using reverse ELISA. Sequence analysis of these mutants revealed alterations focusing on $\mathrm{W}^{84}, \mathrm{P}^{95}, \mathrm{P}^{110}$, or $\mathrm{V}^{129}$. The inclusion bodies of these recombinant proteins overexpressed in E. coli BL21(DE3) were subsequently dissolved using $6 \mathrm{M}$ urea and then refolded by stepwise dialysis. Compared to the unfolded wild-type antigen, the refolded $\mathrm{M} 3 \mathrm{~b}$ antigen $\left(\mathrm{W}^{84} \mathrm{~S}, \mathrm{P}^{110} \mathrm{~S}\right.$ and $\left.\mathrm{V}^{129} \mathrm{~L}\right)$ exhibited an increase of $66 \%$ antigenicity with binding capacity of 0.96 and affinity of $113 \mu \mathrm{M}^{-1}$. Moreover, the $33 \%$ decrease of the production demand suggests that M3b is a potential substitute for anti-HCV antibody detection.
\end{abstract}

\section{Introduction}

The hepatitis $\mathrm{C}$ virus (HCV) infected 3\% world population [1] and its asymptomatic presentation years after infection had been labeled as "silent epidemic" [2]. Approximately $75 \%$ to $85 \%$ of the infected individuals develop chronic disease which may progress to liver cirrhosis and hepatocellular carcinoma $[1,3]$. HCV is also a major etiology agent for blood transfusion-associated with non-A, non-B hepatitis $[1,4]$. The reduction of the posttransfusion HCV incidence largely depends on proper screening of the blood donors. The most common screening methods are based on ELISA (enzyme-linked immunosorbent assay) or NAT (nucleic acid amplification technology) to detect anti HCV antibodies or HCV RNA in serum. NAT could identify low level viremia in very early HCV infection even when the antibodies are not yet present. However, its time-consuming, contamination potential, and less reproducibility limit the clinical application of NAT. ELISA is hence still a favorable use for its relatively cheap and rapid output.

HCV belonging to the Flaviviriadae family has a single stranded positive-sense RNA genome of approximately $9.6 \mathrm{~kb}$. It encodes a single open reading frame of about 3000 amino acid polyprotein which is then cleaved by viral and cellular proteases into mature viral proteins: core protein, envelope glycoproteins (E1 and E2), and six nonstructural proteins (NS2, NS3, NS4a, NS4b, NS5a, and NS5b) $[5,6]$. The HCV core protein, as well as the nonstructural proteins NS3 and NS5, has been commonly used as a coating antigen for the commercial ELISA diagnostic products (MUREX, MP, ORTHO, INNOTEST, and GBC) $[7,8]$. Nonetheless, $\mathrm{HCV}$ core is the major coating antigen for detecting the early-phase infection before seroconversion [9].

$\mathrm{HCV}$ core protein consists of three domains: a basic and hydrophilic region (domain I; residues 1 to 118), a C terminal hydrophobic domain (domain II; residues 119 to 173), and the last hydrophobic signal sequence (domain III; residues 174 to 191). Domain I that includes numerous positively charged amino acids involved in RNA binding contains the immunodominant antigenic sites [10]. The recombinant core protein has been expressed in COS cells, insect cells, $E$. coli, or using the in vitro translation system [11]. Most of the recombinant core proteins were expressed in inclusion body and purified under denaturing condition [12-14]. The inclusion body form is beneficial for industrial production; however, a proper antigenic property which could represent the infection form is still lacking. 
In this study, random mutagenesis was employed to generate a library of recombinant clones to express random mutants of HCV core domain I. For efficient screening of this library, a reverse-ELISA was established as shown in Figure S1. Five of 616 mutants were selected and overexpressed in $E$. coli and the recombinant proteins all form inclusion bodies. The insoluble proteins dissolved in urea were then purified and refolded by stepwise dialysis to remove urea. Finally, kinetic analysis of the purified proteins was performed and the results were compared for a possible mechanism of the antigenicity enhancement.

\section{Materials and Methods}

2.1. Chemicals. All reagents used in the study were of analytical grade and purchased from Sigma or Merck.

2.2. Bacterial Strains. The E. coli strain BL21 (DE3) (E. coli $\mathrm{B} \mathrm{F}^{-} d c m$ omp $T h s d S\left(r_{B}{ }^{-} m_{B}{ }^{-}\right)$gal $\left.\lambda(\mathrm{DE} 3)\right)$ and E. coli strain XL1-Red (E. coli endA1 gyrA96 thi-1 hsdR17 supE44 relA1 lac mutD5 mutS mutT Tn10 $\left.\left(\mathrm{Tet}^{r}\right)\right)$ from Stratagene were, respectively, used for the protein expression and random mutagenesis experiments. Talon SuperFlow Metal Affinity resin (BD Bioscience) was used for protein purification. All reagents are biochemical or molecular biology grade (Merck and Sigma), and the reagents used in ELISA were supplied by GBC (General Biologicals Corp., Taiwan).

2.3. Seroconversion Panels. Two seroconversion panel systems including BBI panel and in-house panel of GBC were used. The international BBI panel containing 3 negative samples (HCV 10017, HCV 10026, and HCV 10058) and one positive control (HCV 10165) were purchased from BBI (BBI Diagnostics Boston Biomedica, Inc, USA). In-house panel contains 4 negative samples including 3HCV3-340 (Lot C59306NCT), P4 (Lot C56AP4), P5 (Lot C56AP5), and P6 (Lot C588P6), and 4 positive controls 3HCV3-330 (Lot C59305PCT), P1 (high titer, Lot C588P1), P2 (medium titer, Lot C579P2), and P3 (low titer, Lot C579P3).

2.4. Construction of the Recombinant HCV Core Antigen. The plasmid carrying the gene coding for HCV core was a gift from GBC ([15]; GenBank accession number M84754). The plasmid was digested with BamHI and XhoI (New England BioLabs), and the fragment of about $500 \mathrm{bps}$ was collected and purified using Qiaquik Gel Extraction Kit (Qiagen). The purified fragment was ligated into BamHI/ XhoI site of pET20b with T4 DNA ligase (Takara Bio Inc.) and the ligation mixture was transferred into E. coli XL10-Gold (Stratagene). The resulting plasmid, namely, pET-Wt contains domain I (amino acid residues 1 to 123) of HCV core (GenBank accession number M84754) and the neighboring pelB leader and His tag at the $\mathrm{N}$ and $\mathrm{C}$ termini, respectively.

2.5. Random Mutagenesis of the HCV Core Antigen. The plasmid pET-Wt was transferred into the mutator E. coli XL1-Red and subsequently spread on LBA plate (Luria
Bertani plate supplemented with $100 \mu \mathrm{g} / \mathrm{mL}$ ampicillin). After incubation at $37^{\circ} \mathrm{C}$ for $18 \mathrm{hr}$, colonies were pooled and resuspended in $3 \mathrm{~mL}$ LBA broth. Aliquot of the suspension was added into $3 \mathrm{~mL}$ LBA broth and incubated at $37^{\circ} \mathrm{C}$ for $15 \mathrm{hr}$. After repeating the subculture procedure 10 times, the plasmid DNA was extracted and transferred into E. coli BL21 (DE3), and the transformed E. coli was then screened by its antigenicities.

2.6. Antigenicity Screening by Reverse-ELISA. A single colony on LBA plate was selected and inoculated into $200 \mu \mathrm{L} \mathrm{LBA}$ broth in a 96 well microplate. After $24 \mathrm{hr}$ incubation at $37^{\circ} \mathrm{C}$, $100 \mu \mathrm{L}$ of bacterial culture was lysed by adding $100 \mu \mathrm{L}$ LBA broth containing lysozyme $(10 \mathrm{mg} / \mathrm{mL})$. The cell lysates were then used for antigenicity screening. For high throughput screening, a reverse-ELISA (see Figure S1 of the Supplementary Material available online at doi:10.1155/2011/359042), in which an antigen is sandwiched by antibodies, was established for the titration of antigen. Essentially, the cell lysates was transferred to another 96 well microplate $(100 \mu \mathrm{L} /$ well $)$ which was precoated with $100 \mu \mathrm{L}$ of the antibody from GBC seroconversion panel (GBC positive control 3HCV3330 , which has been diluted 200 -fold in $10 \mathrm{mM}$ Tris base $\mathrm{pH}$ 9.5). The microplate was then incubated for $1 \mathrm{hr}$ at $37^{\circ} \mathrm{C}$. After washing, $100 \mu \mathrm{L}(0.2 \mu \mathrm{g} / \mathrm{mL})$ of the monoclonal antibody (Abcam ab18664-250 specific to hepatitis $C$ virus NS3) conjugated with horseradish peroxidase was added and the incubation continued for $30 \mathrm{~min}$ at $37^{\circ} \mathrm{C}$. The microplate was again washed and then developed by adding $100 \mu \mathrm{L}$ of $3,3^{\prime}, 5,5^{\prime}$-tetramethylbenzidine in the dark for $30 \mathrm{~min}$ at room temperature. The peroxidase reaction was terminated by adding $100 \mu \mathrm{L}$ of $2 \mathrm{~N} \mathrm{H}_{2} \mathrm{SO}_{4}$ and the absorbance at 450-650 nm was measured using ELISA reader (Molecular Devices).

\subsection{Expression and Purification of the Recombinant HCV Core} Antigen. The E. coli strain BL21 (DE3) harboring each of the recombinant plasmids was grown in $3 \mathrm{~mL}$ LBA for $8 \mathrm{hr}$ at $37^{\circ} \mathrm{C}$. Ten microlitres of the culture was refreshed grown in $50 \mathrm{~mL}$ of LBA at $37^{\circ} \mathrm{C}$ for $15 \mathrm{hr}$ and then $5 \mathrm{~mL}$ of the culture was added into 2 liters of LBA. The culture was grown at $37^{\circ} \mathrm{C}$ till the absorbance $(\mathrm{OD} 600)$ reach $\sim 1.0$, the inducer IPTG $(0.5 \mathrm{mM})$ was then added and the incubation continued for $4 \mathrm{hr}$ at $37^{\circ} \mathrm{C}$. The bacteria was collected by centrifugation $\left(6,000 \times \mathrm{g}, 15\right.$ minutes, $\left.4^{\circ} \mathrm{C}\right)$, suspended with $100 \mathrm{~mL}$ buffer A $(50 \mathrm{mM}$ Tris base, $0.5 \mathrm{M} \mathrm{NaCl}, 100 \mathrm{mM}$ sucrose, $5 \mathrm{mM}$ imidazole and $10 \%$ glycerol at $\mathrm{pH} 8.0$ ), and finally lysed by Homogenizer (EmuFsiFlex-C5). Total cell lysate was precipitated by centrifugation $(10,600 \times \mathrm{g}$, $60 \mathrm{~min}, 4^{\circ} \mathrm{C}$ ) and the collected pellet was resuspended with $100 \mathrm{~mL}$ buffer B $(6 \mathrm{M}$ urea, $50 \mathrm{mM}$ Tris base, $0.5 \mathrm{M}$ $\mathrm{NaCl}, 100 \mathrm{mM}$ sucrose, $5 \mathrm{mM}$ imidazole and $10 \%$ glycerol at $\mathrm{pH} 8.0)$. After the suspension subjected to incubation for $20 \mathrm{hr}$ at $4^{\circ} \mathrm{C}$ centrifugation $\left(10,600 \times \mathrm{g}, 60 \mathrm{~min}, 4^{\circ} \mathrm{C}\right)$, the collected supernatant was applied to the Talon affinity column (TALON SuperFlow Metal Affinity Resin, $2.6 \mathrm{~cm} \times$ $10 \mathrm{~cm}$ ) pre-equilibrated using buffer B. After washing away 
the unbound proteins using 10 column volumes of buffer $\mathrm{B}$, the target protein was eluted using a linear gradient of imidazole concentration from $5 \mathrm{mM}$ to $100 \mathrm{mM}$. The purified HCV core antigen was pooled as "unfolded antigen" and stored at $4^{\circ} \mathrm{C}$ before use.

2.8. Refolding of the Unfolded HCV Core via Dialysis. The unfolded $\mathrm{HCV}$ core antigen was dialyzed against 50 volumes of buffer C (20 mM Tris base and $20 \mathrm{mM} 2$-Mercaptoethanol at $\mathrm{pH} 7.6)$ for $8 \mathrm{~h}$ at $4^{\circ} \mathrm{C}$ using a molecular-porous membrane tubing (SPECTRUM, MWCO: 6 to 8,000). The dialysis was repeated twice, followed by 5 times dialysis against buffer $\mathrm{D}(20 \mathrm{mM}$ Tris base $\mathrm{pH} 7.6)$ for $12 \mathrm{hr}$ at $4^{\circ} \mathrm{C}$. The resulting dialysis solution was centrifuged $\left(10,600 \times \mathrm{g}, 60 \mathrm{~min}, 4^{\circ} \mathrm{C}\right)$ to remove the insoluble portion. The supernatant containing the soluble refolded antigen was then subjected to protein concentration determination, SDS-PAGE analysis for the protein homogeneity, and ELISA to evaluate the antibody binding capacity.

2.9. HPLC Performance. Purity of the proteins was analyzed using high performance liquid chromatography (HPLC; 600E Multisolvent Delivery System, Waters Corporation, USA) with an Ultra High Resolution SEC column (BioSuite $125,4 \mu \mathrm{m}$, Waters Corporation, USA) under $4^{\circ} \mathrm{C}$. The insoluble proteins were separated and eluted with $0.15 \mathrm{M}$ phosphate buffer $(\mathrm{pH} 6.8)$ and $3 \mathrm{M}$ urea at a flow rate of $0.3 \mathrm{~mL} / \mathrm{min}$, while the refolded antigens were eluted using $0.15 \mathrm{M}$ phosphate buffer ( $\mathrm{pH}$ 6.8) without urea. The data determined by the changes of absorbance at $280 \mathrm{~nm}(996$ Photodiode Array Detector, Waters Corporation, USA) were collected and processed using Empower 2 Chromatography Data Software (Waters Corporation, USA).

2.10. HCV ELISA. The purified HCV core antigen (the unfolded forms in urea solution while the refolded forms in solution D) diluted to the concentrations of 0.03 to $10 \mu \mathrm{g} / \mathrm{mL}$ with coating buffer ( $20 \mathrm{mM}$ phosphate buffer, $\mathrm{pH} 6$ ) was applied to microplates and the plates were allowed to stand at $4^{\circ} \mathrm{C}$ for at least $20 \mathrm{hr}$. The microplates were then washed, overcoated, and dried for $15 \mathrm{hr}$. Two seroconversion panel systems, including BBI panel and inhouse panel of GBC, diluted 20-fold with Specimen Diluent C (3HC03-350 Lot C58C06SDP) were then added to the microplates for $1 \mathrm{hr}$ at $37^{\circ} \mathrm{C}$ and used as the primary antibody. Anti-human IgGHRPO conjugates was applied as the secondary antibody for $30 \mathrm{~min}$ at $37^{\circ} \mathrm{C}$. The microplates were then washed and developed using $3,3^{\prime}, 5,5^{\prime}$-tetramethylbenzidine. The absorbance data were compiled statistically as $S / C o$ value ( $S$ : sample value; Co: cutoff value). The cut-off value was calculated as the negative control OD plus positive control OD divided by $4(\mathrm{Co}=\mathrm{NCx}+\mathrm{PCx} / 4)$. The $\mathrm{S} / \mathrm{Co}$ value was calculated as the sample OD divided by the cut-off value. Samples with an absorbance equal to or higher than the cut-off value, that is, S/Co value greater than 1 , were considered to be initially reactive in the assay.

\section{Results and Discussion}

3.1. Generation and Screening of HCV Core Antigen Mutants. The culture mutator E. coli XL1-Red carrying the plasmid pET-Wt encoding the domain I of HCV core flaked with pelB leader and His-tag (Figure 1(a)) was refreshed and then subjected to a series of subculture to introduce mutations into the HCV core antigen. After 10 generations, 616 colonies were arbitrarily selected for the antigenicity screening using the reverse ELISA. In the reverse ELISA, HCV core antigen mutant is sandwiched by two kinds of HCV antibodies, the serum antibody of positive control panel and a monoclonal antibody (abcam, ab18664-250). The monoclonal antibody was described as specific to HCV NS3. However, it reacted with our HCV core antigen in previous experiments (data not shown). Besides, it was produced by using a chimeric $\mathrm{HCV}$ polyprotein as its immunogen, and the sequence alignment of this immunogen and HCV core protein showed $90 \%$ identity (see Figure S2). Finally, five of the 616 colonies which exhibiting relatively higher antigenicities than the original pET-Wt were isolated and the plasmids were purified for sequence determination.

\subsection{Isolation and Alignment of the HCV Core Antigen} Mutants. The sequences from the residues 68 to137 of the five mutants were aligned with that of the wild-type antigen. As shown in Figure 1(b), these mutations were mapped to $\mathrm{W}^{84}, \mathrm{P}^{95}, \mathrm{P}^{110}$, and $\mathrm{V}^{129}$. The mutants were named according to the number of residue changed as $\mathrm{Mla}, \mathrm{M} 1 \mathrm{~b}$ (one residue mutation), M2 (two residue mutation), M3a, and M3b (three residue mutation). The alterations included tryptophan or proline to serine or leucine. When analyzed using Burgess Ponnuswamy Scheraga (BPS) method [16], the residue alterations have apparent effects on the secondary structure with respect to random coil fluctuations to help exposure of the residue. Besides, it is believed that the replacement by hydrophilic or less hydrophobic amino acids enhance the solubility of HCV core antigens in aqueous system. A single mutation alters the immunogenic properties via changes of the secondary structure had been reported in the case of HIV [17]. Whether the mutations have similar effects could only be verified until the structure of HCV core is available.

\subsection{Expression and Purification of the Recombinant $\mathrm{HCV}$} Core Antigens. The recombinant proteins of $\mathrm{Wt}$ and the five mutants overexpressed in E. coli BL21 (DE3) all formed inclusion body with deduced molecular mass of $19 \mathrm{kDa}$. After the inclusion bodies dissolved in urea, the denatured proteins were purified by Talon affinity chromatography under denaturing condition with $6 \mathrm{M}$ Urea. In our previous experiments, to remove urea by one-step dialysis against solution D or by above 1000 -fold ( $<6 \mathrm{mM}$ urea) dilution with coating buffer will cause aggregation and precipitation of HCV core antigens. By stepwise dialysis, less precipitates were found and the supernatants containing soluble HCV core antigens 

GRRQP I PKARQP EGRAWAQPGY PWP L YGNEGLGWAGWLV S PRGS R PNWGP TDP RRR S RNLGKV I LEHHHHHH

(a)

Wt (68) LPRRGPRLGVR ATRKTWERSQPRGRRQ PI PKARQP EGRAWAQPGYPWP LYGNEGLGWAGWLVS PRGSR PN

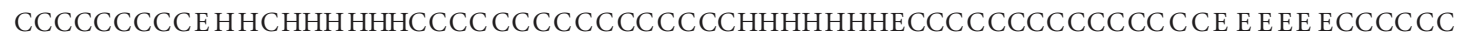

M1a (68) LPRRGPRLGVR ATRKTSERSQPR GRRQP I PKARQPEGRAWAQPGYPWP LYGNEGLGWAGWLVS PRGSR PN

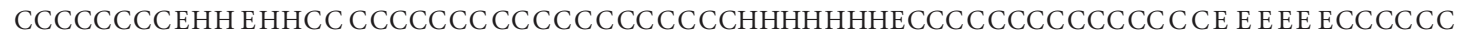

M1b (68) LPRRGPRLGVR A T RKTWERSQPR GRRQP I PKARQP E GRAWAQPGYPWP LYGNEGLGWAGWLLS PRGSR PN

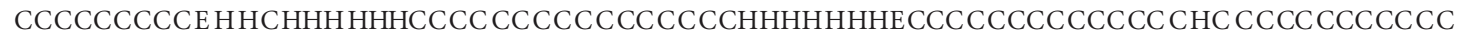

M2 (68) LPRRGPRLGVR ATRKT SERSQPR GRRQP I PKARQPEGRAWAQPGYPWP LYGNEGLGWAGWLLS PRGSR PN CСССССССЕHН EHHCC ССССССС ССССССССССССНHHHHHHECССССССС ССССС СHC ССССССССССС

M3a (68) LPRRGPRLGVRATRKTSERSQPR GRRQLI PKARQPEGRAWAQPGYPWP LYGNEGLGWAGWLLS PRGSR PN

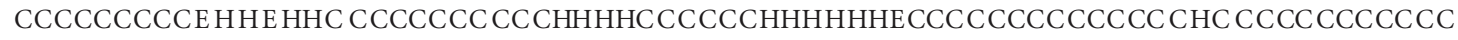

M3b (68) LPRRGPRLGVR ATRKTSERSQPRGRRQP I PKARQPEGRAWA SSGYPWP LYGNEGLGWAGWLLS PRGSR PN

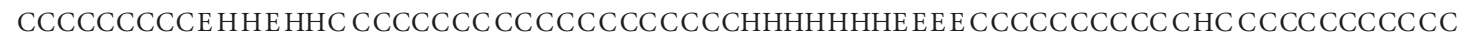

(b)

FIGURE 1: Sequence comparison. (a) The primary sequence of wild-type recombinant HCV core antigen presented in single letter code. It consists of three components: pelB leader (from aa 1 to aa 31 in border-box), HCV core fragment containing domain I (from aa 32 to aa 154 , total $123 \mathrm{aa}$ ), and His tag (from aa 155 to aa 162, underlined). (b) Five mutants with higher antigenicities are aligned with wild-type antigen covering residues 68 to 137 . Four high-frequency mutation points at $\mathrm{W}^{84}, \mathrm{P}^{95}, \mathrm{P}^{110}$, and $\mathrm{V}^{129}$ are in boldface. The mutations are marked with a shaded box. The characters $\mathrm{H}, \mathrm{E}$, and $\mathrm{C}$ stand for alpha helices, beta strands, and random coil, respectively.

were above $95 \%$ purity by SDS-PAGE and HPLC chromatography (see Figure S3).

3.4. HCV ELISA of the Core Mutants. The unfolded or refolded form of Wt or any of the mutant antigens $(4 \mu \mathrm{g} / \mathrm{mL}$ $\times 100 \mu \mathrm{L}$ per well) was used to coat the ELISA microplate individually for the subsequent HCV ELISA. As shown in Figure 2(a), these recombinant antigens were able to readily differentiate the positives (i.e., S/Co > 1) from negative samples (i.e., S/Co < 1) of BBI panels. As shown in Figure 2(b), all the sequentially diluted PCs (positive control of GBC inhouse panel) could be detected by these recombinant antigens except the 70-fold diluted one. The mutations with more residue substitutions ( $\mathrm{M} 3 \mathrm{a}$ and $\mathrm{M} 3 \mathrm{~b}$ ) appeared to enhance the detection sensitivity as assessed with the larger $\mathrm{S} / \mathrm{Co}$ value than the others.
3.5. Comparison of the Detection Sensitivity of the Insoluble and Refolded Proteins. As shown in Figures 3(a) and 3(b), both antigen forms at the concentration of $2 \mu \mathrm{g} / \mathrm{mL}$ exhibited a similar level of antigenicity in the order of $\mathrm{M} 3 \mathrm{~b}>\mathrm{M} 3 \mathrm{a}>$ M2 > M1a > M1b > Wt. The saturated sensitivities of the refolded proteins were 1.19- to 1.27-fold higher than their unfolded forms. The saturated concentrations of the unfolded/refolded antigens were about $0.7 / 0.6 \mathrm{mg} / \mathrm{mL}(\mathrm{M} 3 \mathrm{~b})$, 0.8/0.6 mg/mL (M3a), 0.9/0.7 mg/mL (M2), 0.9/0.9 mg/mL (M1a), $1.0 / 0.8 \mathrm{mg} / \mathrm{mL}$ (M1b), and $0.9 / 0.9 \mathrm{mg} / \mathrm{mL}$ (Wt), indicating the refolding process had no apparent effect on the saturation concentration. As for refolded $\mathrm{M} 3 \mathrm{~b}$ used as the coating antigen to substitute the currently used HCV core antigen (Wt) for the anti-HCV antibody ELISA, it appeared to enhance about $20 \%$ of the antigenicity which allowed reducing about $33 \%$ of the production demand. 


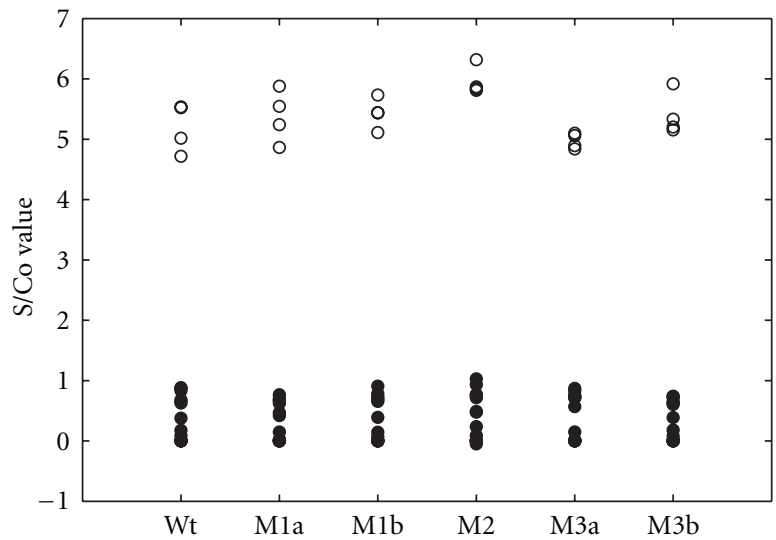

(a)

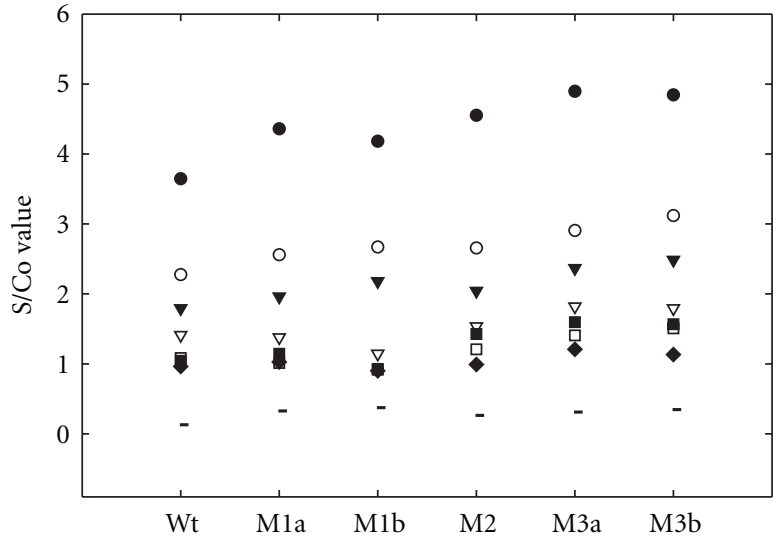

(b)

Figure 2: HCV ELISA for urea-denatured HCV core mutants. The urea-denatured HCV core antigens $(100 \mu \mathrm{L}$ of $4 \mu \mathrm{g} / \mathrm{mL}$ per well) were used to coat the microplate for the detection of anti-HCV antibody of BBI panel (a) and GBC inhouse panel (b). The absorbance data were compiled statistically as S/Co value (S: sample value; Co: cut-off value). The cut-off value was calculated as the negative control OD plus positive control OD divided by $4(\mathrm{Co}=\mathrm{NCx}+\mathrm{PCx} / 4)$. The positive samples (i.e., S/Co $>1$, marked as open circle, lot number HCV10165-6 9) could be clearly separated from the negative samples (i.e., S/Co < 1, marked as closed circle, lot number HCV10017-1 7, HCV10026-1 5, HCV10058-1 3) of BBI panel. In Figure 2(b), the primary antibodies used are sequentially diluted in 10-fold order from 10x to 70x of the PC (positive control) and NC (negative control). Co value was calculated by the average OD values of NC and 20x PC. The

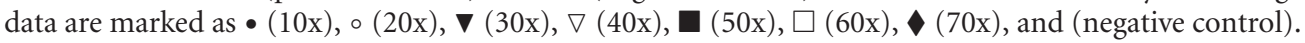

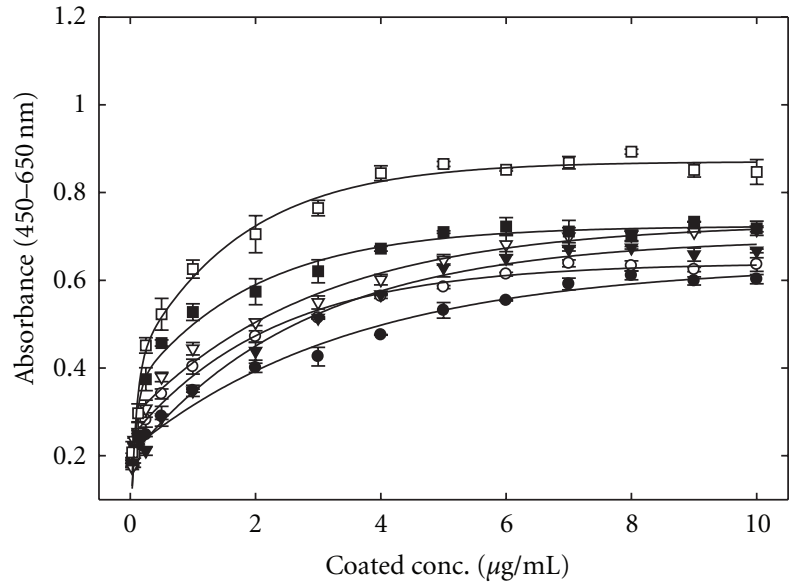

(a)

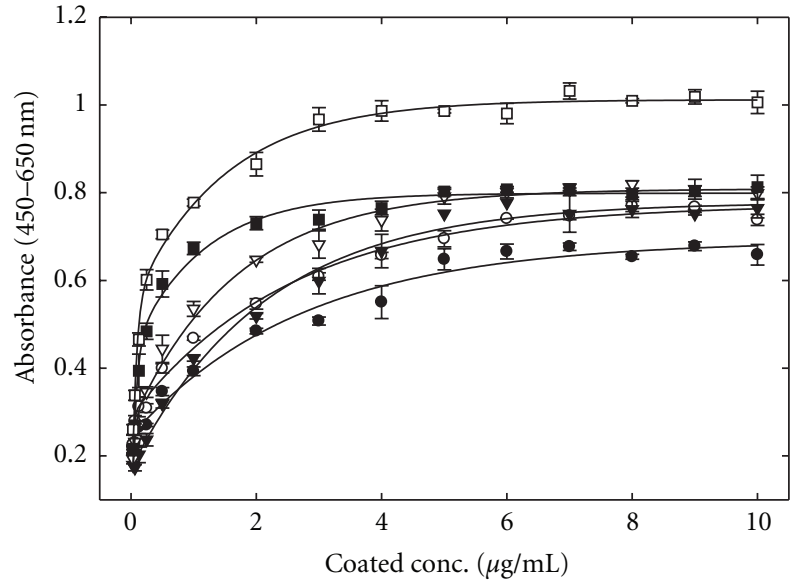

(b)

Figure 3: Saturation curves for urea-denatured (a) and refolded (b) forms of HCV core antigens. Antigenicity of unfolded (a) and refolded (b) forms of HCV core antigens were examined by ELISA using the microplate that had been coated with different amounts of Wt (•), Mla $(\circ), \operatorname{M1b}(\mathbf{\nabla}), \operatorname{M} 2(\nabla)$, M3a $(\boldsymbol{\square})$, and M3b( $\square)$.

3.6. Kinetic Analysis. As shown in Table 1, comparison of the Langmuir equilibrium constant $\left(\mathrm{K}_{\mathrm{L}}\right)$ and maximum binding capacity $\left(\mathrm{A}_{\max }\right)$, assessed using the reciprocals of absorbance $(1 / \mathrm{A})$ and the antigen concentration $(1 /[\mathrm{S}])$ (see Figure S4), revealed that either mutation enhanced the affinity and binding capacity to the antibody. The refolding procedure further increased the binding capacity $\left(\mathrm{A}_{\max }\right)$ and the affinity index $\left(\mathrm{K}_{\mathrm{L}}\right)$. The mutant M3b antigen exhibited the highest affinity and binding capacity. When compared to the unfolded Wt antigen, the refolded M $3 \mathrm{~b}$ showed an increase of about $38 \%$ of $\mathrm{K}_{\mathrm{L}}$ (from 82 to $113 \mu \mathrm{M}^{-1}$ ) and $113 \%$ of $\mathrm{A}_{\max }$ (from 0.45 to $0.96)$.

\section{Conclusion}

Five HCV core antigen mutants with an improved antigenicity were obtained via random mutagenesis and reverseELISA screening. The mutant-carrying plasmids were individually expressed in E. coli, the inclusion bodies formed were dissolved in urea and purified, the denatured protein refolded by dialysis, and the dialyzed proteins were used to coat the microplates for the ELISA of anti-HCV antibody. Sequence analysis of the mutated residues suggested that the random coils play a critical role in the antigenicity enhancement. Kinetic analysis using Langmuir simulation further 
TABLE 1: $K_{L}$ (affinity) and $A_{\max }$ (maximum binding capacity) of HCV core antigens.

\begin{tabular}{|c|c|c|c|c|c|c|c|c|c|c|c|c|c|c|c|c|c|c|}
\hline \multirow[b]{2}{*}{ Core protein } & \multicolumn{3}{|c|}{ Wild type } & \multicolumn{3}{|c|}{ M1a } & \multicolumn{3}{|c|}{ M1b } & \multicolumn{3}{|c|}{ M2 } & \multicolumn{3}{|c|}{ M3a } & \multicolumn{3}{|c|}{ M3b } \\
\hline & $\mathrm{U}^{\mathrm{a}}$ & $\mathrm{R}^{\mathrm{b}}$ & $\mathrm{R} / \mathrm{U}$ & $\mathrm{U}$ & $\mathrm{R}$ & $\mathrm{R} / \mathrm{U}$ & $\mathrm{U}$ & $\mathrm{R}$ & $\mathrm{R} / \mathrm{U}$ & $\mathrm{U}$ & $\mathrm{R}$ & $\mathrm{R} / \mathrm{U}$ & $\mathrm{U}$ & $\mathrm{R}$ & $\mathrm{R} / \mathrm{U}$ & $\mathrm{U}$ & $\mathrm{R}$ & $\mathrm{R} / \mathrm{U}$ \\
\hline $\mathrm{K}_{\mathrm{L}}\left(\mu \mathrm{M}^{-1}\right)$ & $82 \pm 8$ & $69 \pm 5$ & 0.9 & $74 \pm 7$ & $64 \pm 4$ & 0.9 & $43 \pm 3$ & $39 \pm 3$ & 0.9 & $77 \pm 6$ & $61 \pm 4$ & 0.8 & $93 \pm 8$ & $115 \pm 5$ & 1.2 & $87 \pm 10$ & $113 \pm 10$ & 1.3 \\
\hline$A_{\max }\left(10^{-2}\right)$ & $45 \pm 2$ & $54 \pm 2$ & 1.2 & $54 \pm 2$ & $64 \pm 2$ & 1.2 & $55 \pm 3$ & $66 \pm 3$ & 1.2 & $58 \pm 2$ & $74 \pm 2$ & 1.3 & $65 \pm 2$ & $78 \pm 1$ & 1.2 & $80 \pm 3$ & $96 \pm 3$ & 1.2 \\
\hline $\mathrm{R}_{\mathrm{sqr}}$ & 0.96 & 0.92 & & 0.97 & 0.94 & & 0.97 & 0.96 & & 0.97 & 0.95 & & 0.98 & 0.94 & & 0.93 & 0.91 & \\
\hline
\end{tabular}

confirmed that the antigenicity has been improved via increasing the affinity and binding capacity to the antibody. All five mutants appeared to contain either change of $\mathrm{W}^{84}$ or $\mathrm{V}^{129}$, the ones harbor additional mutation on $\mathrm{P}^{95}$ or $\mathrm{P}^{110}$ had better antigenicity. It would be of interest to investigate that if a significant increase of the antigenicity could be observed after all four residues of the protein are altered.

\section{Acknowledgments}

The work was supported by the National Science Council, Taiwan, NSC 97-2320-B-009-001-MY3 and General Biologicals Corporation in Hsinchu Science Park, Taiwan.

\section{References}

[1] Y. Mori, K. Moriishi, and Y. Matsuura, "Hepatitis C virus core protein: its coordinate roles with PA28y in metabolic abnormality and carcinogenicity in the liver," International Journal of Biochemistry and Cell Biology, vol. 40, no. 8, pp. 1437-1442, 2008.

[2] M. A. Feitelson, Hepatitis C Virus: From Laboratory to Clinic, Cambridge University Press, Cambridge, UK, 2004.

[3] J. Czepiel, G. Biesiada, and T. Mach, "Viral hepatitis C," Polskie Archiwum Medycyny Wewnetrznej, vol. 118, no. 12, pp. 734740, 2008.

[4] K. Oka, M. Nagano-Fujii, I. Yoshida et al., "Hepatitis C virus core protein selectively inhibits synthesis and accumulation of p21/Waf1 and certain nuclear proteins," Microbiology and Immunology, vol. 47, no. 6, pp. 429-438, 2003.

[5] D. Moradpour, F. Penin, and C. M. Rice, "Replication of hepatitis C virus," Nature Reviews Microbiology, vol. 5, no. 6, pp. 453-463, 2007.

[6] F. Penin, J. Dubuisson, F. A. Rey, D. Moradpour, and J. M. Pawlotsky, "Structural biology of hepatitis C virus," Hepatology, vol. 39, no. 1, pp. 5-19, 2004.

[7] F. Ferrer, M. J. Candela, C. Garcia, L. Martinez, J. Rivera, and V. Vicente, "A comparative study of two third-generation antihepatitis C virus ELISAs,” Haematologica, vol. 82, no. 6, pp. 690-691, 1997.

[8] P. Martin, F. Fabrizi, V. Dixit et al., "Automated RIBA hepatitis $\mathrm{C}$ virus (HCV) strip immunoblot assay for reproducible HCV diagnosis," Journal of Clinical Microbiology, vol. 36, no. 2, pp. 387-390, 1998.

[9] S. R. Lee, J. Peterson, P. Niven et al., "Efficacy of a hepatitis $\mathrm{C}$ virus core antigen enzyme-linked immunosorbent assay for the identification of 'window-phase' blood donations," Vox Sanguinis, vol. 80, no. 1, pp. 19-23, 2002.

[10] L. S. Ai, Y. W. Lee, and S. S. L. Chen, "Characterization of hepatitis $\mathrm{C}$ virus core protein multimerization and membrane envelopment: revelation of a cascade of core-membrane interactions," Journal of Virology, vol. 83, no. 19, pp. 9923-9939, 2009.

[11] M. Esumi, N. Hayashi, H. Takahashi et al., "Immunoreactive core peptides of hepatitis C virus produced in Escherichia coli and in vitro DNA amplification-restricted transcriptiontranslation system," Journal of Virological Methods, vol. 59, no. 1-2, pp. 91-98, 1996.

[12] S. Boulant, M. Becchi, F. Penin, and J. P. Lavergne, "Unusual multiple recoding events leading to alternative forms of hepatitis C virus core protein from genotype 1b," Journal of Biological Chemistry, vol. 278, no. 46, pp. 45785-45792, 2003.

[13] D. Y. Chien, Q. L. Choo, A. Tabrizi et al., "Diagnosis of hepatitis $\mathrm{C}$ virus (HCV) infection using an immunodominant chimeric polyprotein to capture circulating antibodies: reevaluation of the role of HCV in liver disease," Proceedings of the National Academy of Sciences of the United States of America, vol. 89, no. 21, pp. 10011-10015, 1992.

[14] L. R. You, C. M. Chen, T. S. Yeh et al., "Hepatitis C virus core protein interacts with cellular putative RNA helicase," Journal of Virology, vol. 73, no. 4, pp. 2841-2853, 1999.

[15] P. J. Chen, M. H. Lin, K. F. Tai, P. C. Liu, C. J. Lin, and D. $\mathrm{S}$. Chen, "The Taiwanese hepatitis $\mathrm{C}$ virus genome: sequence determination and mapping the 5' termini of viral genomic and antigenomic RNA," Virology, vol. 188, no. 1, pp. 102-113, 1992.

[16] A. W. Burgess, P. K. Ponnuswamy, and H. A. Sheraga, "Analysis of conformations of amino acid residues and prediction of backbone topography in proteins," Israel Journal of Chemistry, vol. 12, no. 2, pp. 239-286, 1974.

[17] S. K. Lee, G. A. Pestano, J. Riley et al., "A single point mutation in HIV-1 V3 loop alters the immunogenic properties of rgp120," Archives of Virology, vol. 145, no. 10, pp. 2087-2103, 2000. 

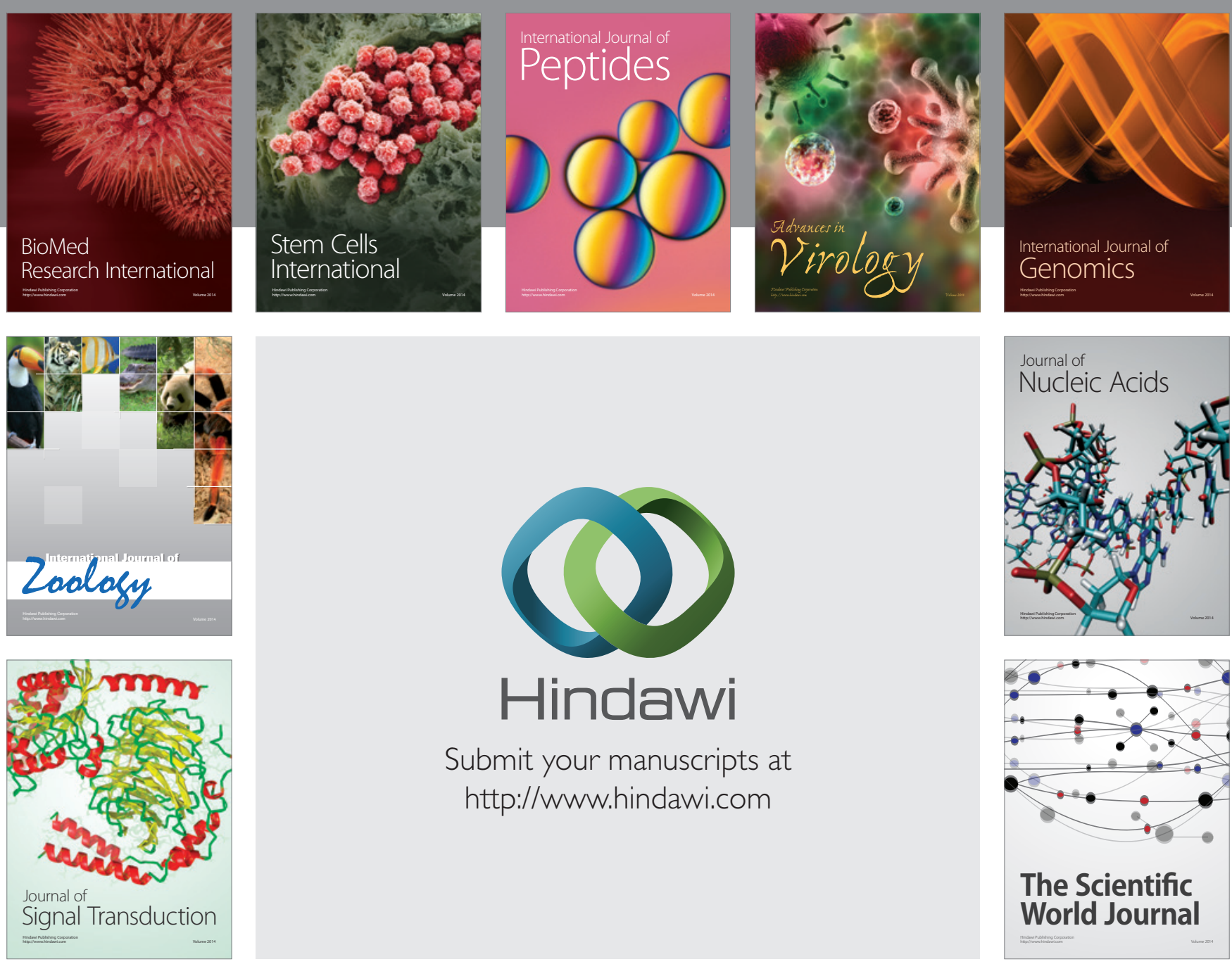

Submit your manuscripts at

http://www.hindawi.com
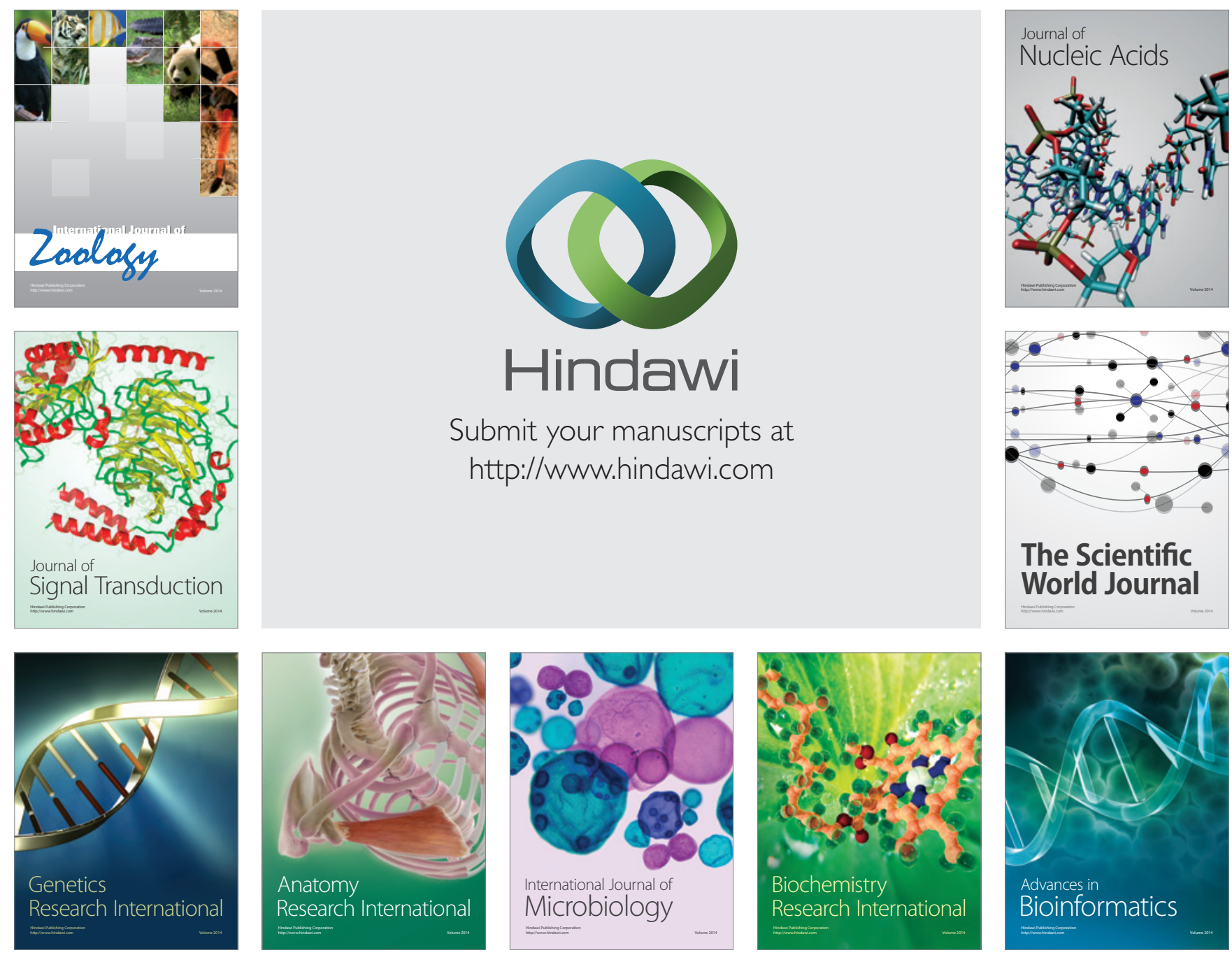

The Scientific World Journal
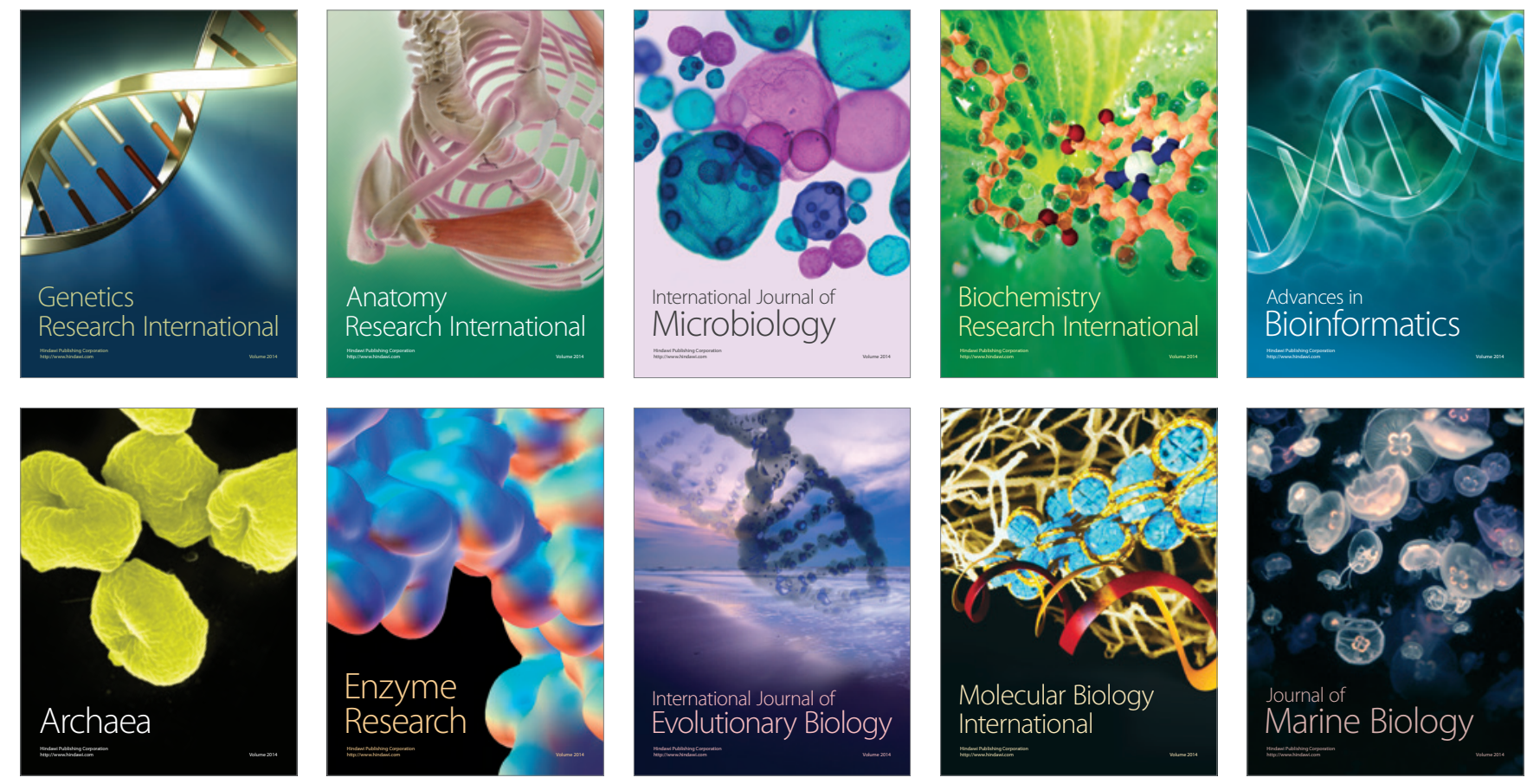